\title{
Intercountry adoption and the social production of abandonment
}

\section{Hogbacka, Riitta}

2019-01

Hogbacka , R 2019 , ' Intercountry adoption and the social production of abandonment ' , International Social Work, vol. 62 , no. 1 , pp. 271-282 . https://doi.org/10.1177/0020872817725142

http://hdl.handle.net/10138/308865

https://doi.org/10.1177/0020872817725142

acceptedVersion

Downloaded from Helda, University of Helsinki institutional repository.

This is an electronic reprint of the original article.

This reprint may differ from the original in pagination and typographic detail.

Please cite the original version. 


\title{
Intercountry adoption and the social production of abandonment
}

\author{
Abstract \\ Although the objective of intercountry adoption is to provide parentless children with \\ families, it also has other unintended consequences. Postcolonial theorists have shown \\ that the intercountry adoption system is shaped by unequal power relations between the \\ Global North and South. Drawing on interviews with South African adoption social \\ workers and birth mothers, this article shifts attention from Global North perspectives to \\ those of the Global South. By focusing on the circumstances of how children become \\ available for adoption, some of the ways in which the adoption system participates in \\ creating the pool of "abandoned" children are explicated.
}

Keywords: intercountry adoption, social workers, birth mothers, abandonment, South Africa

\section{A postcolonial perspective on intercountry adoption}

The usual understanding of intercountry adoption revolves around the notion of the abandoned child in need of (adoptive) parents. The task of the adoption system then becomes finding a family for such a child. This notion is, however, ethnocentric and is based on the gaze from the Global North. The focus is solely on the child as free- 
standing and as an orphan, even though research shows that most of these children have living birth parent(s) or other family members (Cantwell 2014, 75). Focusing on the child and leaving the family of origin out of the picture also directs attention away from the structural circumstances of how the child became available for adoption. The interconnections between the receiving countries of the Global North and the sending countries of the Global South are thus obscured.

My aim in this article is to shift the angle and to look at the picture from the other side. Such a perspective can be described as postcolonial. What is common to the various strands of postcolonial theory is the attention given to the unequal relations between the Global North and South. The colonial legacy is still influential in that wealth continues to accrue to the Global North, which has power over the South. The old colonial racial hierarchy and racialized prejudice also linger. White Global North is taken to represent the civilised and advanced centre, while the non-white South is depicted as inferior and in need of rescue. Part of this power imbalance is the distorted view of the world in which the definitions, values and practices of the Global North are taken to be universal and superior and are imposed on the Global South (see Bhambra 2014; Niewenhuys 2013).

In adoption studies, a postcolonial perspective means first paying attention to the broader context. It is vital to place transnational adoption within the context of the Global North-South divide, as adopted children are primarily transferred from the South 
to the North. The Global North benefits from its unequal economic relations with the Global South. Its affluence is created in part from holding the South back (Castles 2003, 18; Pratt 2002, 29). The Global North and the adopting nations are thus implicated in the maintaining of material disparities in the South and the countries of origin, which is in the background of most adoptions (Högbacka 2016; Bos 2007; Fonseca 2011; Giberti 2000; Roby \& Matsumura 2002). Material poverty is then used as a justification for adoption (see Smolin 2007a). This link needs to be explicated.

Secondly, a postcolonial approach focuses on the understandings of the birth mothers (and where applicable the genetic fathers and other kin) of adopted children. Such a view questions the assumed values, norms and practises of what are considered proper families and proper parenting in the North. The exclusive family model of the Global North localises proper care within the domesticity of one set of parents and their children, always staying together in the parental home. The inclusive model prevalent in the South is characterised by a more varied set of carers and places of care, including kin care and temporary separations between parent(s) and children (see Högbacka 2016). Informal kinship care, which does not entail a permanent separation between parents and children, is also widespread in South Africa (Hall et al. 2014, 92). When the Global North applies the exclusive model of child care to the Global South, it tends to see the children as lacking proper families or proper care (Penn 1999; 2009). Coupled with ethnocentric notions of superiority, this attitude results in the notion of rescuing 
children from inferior others to live with better middle-class families in the Global North (King 2008/2009; Perry 1998).

In this article, I will juxtapose the adoption system's views and those of the birth mothers. What does abandonment look like from the perspective of birth mothers? In what ways does the adoption system contribute to the formation of the pool of abandoned children? I draw on interviews with South African adoption social workers and birth mothers from my larger study on inequality and transnational adoption (Högbacka 2016). I will specifically utilise the interviews with 10 adoption social workers and 35 birth mothers I conducted in four locations in South Africa during 20062009. The social workers were mostly white and came from the three biggest adoption organisations and included some independent social workers. They all specialized in adoption and had experience of working with birth mothers. The birth mothers, who were primarily black South Africans, were aged between 14 and 43. Some were still pregnant at the time of the interview, but most had already placed the child for adoption previously, some more than five years earlier. I located the birth mothers through maternity homes and through the social workers, who thus acted as gate-keepers. I assured all interviewees that their participation was entirely voluntary. I have also changed all names. 


\section{Abandoning the mothers}

It is useful to start with dictionary meanings of abandonment. The following pertinent meanings for "to abandon" can be found in major dictionaries:

To leave and never return to (someone who needs protection or help); to withdraw protection, support, or help from; to give up with the intent of never again claiming a right or interest in (Merriam-Webster)

To leave a place, thing, or person, usually for ever (Cambridge Dictionary)

Cease to support or look after (someone); desert; condemn someone or something to (a specified fate) by ceasing to take an interest in them; give up completely (a practice or a course of action) (Oxford Living

\section{Dictionaries)}

Three distinct meanings of abandoning a person can be discerned from the dictionary entries. First, they all underline leaving and the permanence of the break. In other words, to abandon someone is to walk away from this someone with the intention of making a permanent break with him or her. Secondly, abandoning implies not caring about someone, not taking an interest in, and not wanting to know what happens to them. "Abandoned" thus has the connotation of "unwanted". Thirdly, abandoning includes the aspect of withdrawing help or support from someone in need, in other words, leaving someone to their own devices. 
I will come back to these meanings later, but first it is enlightening to change the perspective from abandoned children to abandoned mothers. Abandoning in this sense refers to the withdrawal of assistance. Even though poverty is not an acceptable reason for adoption, in practice this is often the case. The United Nations General Assembly (2010) has, for instance, clearly stated that poverty "should never be the only justification for the removal of a child from parental care, for receiving a child into alternative care, or for preventing his/her reintegration, but should be seen as a signal for the need to provide appropriate support to the family." (cited in Cantwell 2014, 73) Nevertheless, the Hague Convention on Protection of Children and Co-Operation in Respect of Intercountry Adoption (HCCH 1993), which is the major international treaty regulating intercountry adoptions, remains silent on this topic. In practice, material lack is a major driving factor of adoptions, and impoverished birth mothers are not offered assistance or help in order to keep their child. The adoption system leaves the mothers to their own devices.

My South African case study showed that most birth mothers did not have a real choice. They were in effect presented with only one option: if they could not afford to raise their child themselves, the only alternative offered to them was adoption. This was evident both from the adoption social workers' accounts and from what the birth mothers told me. The social workers were very aware of the almost total lack of resources at their disposal. They were unanimous that the most common reasons for 
adoptions were material poverty and unemployment. Social workers were not able to influence these structural issues or to alleviate their effects. As they told me, they could not offer any material help, although this was what most impoverished mothers would have wanted and needed. This is evident in the following social worker's account, and was shared by many.

Because the majority 99 per cent of the mums giving up are giving up purely due poverty and just helplessness and hopelessness and destitution. [...] They're not giving up, because they think it's the best thing for the baby or because they think that they're too young to look after the child. They're giving up, because they can't do anything else. [...] We say to them in the counselling, you know, it's adoption or keeping. [...] So, you're not offering them anything. (Adoption social worker, interview No. 3)

Many social workers in fact told me that they tried to bend the rules and had kept the babies in children's homes or other temporary places of safety for several months while the mothers tried to find a job or improve their situations. In most cases, however, a few months were not sufficient. Some social workers experienced self-doubt and were sceptical about the adoption system. Some felt bad that all they could offer was the removal of the child. 
I just feel so helpless when they come, they say, you know, I just want temporary care and I have to say but there isn't. These are your two options [keeping or adoption], which is horrible. I mean, I just feel, what kind of a job am I doing here. (Adoption social worker, interview No. 7).

What was also evident from the social workers' accounts was that many birth mothers were experiencing temporary financial difficulties. Although they could not make ends meet at that moment, their situation could and sometimes did change after one or two years. At that point adoptions had already been arranged and there was nothing to be done. As some social workers said, if an interim alternative was available in which birth mothers were provided food, shelter and child care so that they could look for jobs, most would not have gone through with the adoption. Although a child-support grant is available to South African citizens, it is of low monetary value (R320 equalling about 27 USD per month in 2014) (South African government info 2014), and thus does not enable the raising of a child.

The narratives of the birth mothers confirmed these observations. Although a minority of them were in better material situations with more options, the majority faced insurmountable difficulties. They were in effect placed in situations where they had no real alternatives. In order for them, their older children and kin to survive, they had to place the last-born infant for adoption. Despite the rhetoric of choice prevalent in the adoption system, most birth mothers' actions resembled coerced separations. Adoption 
may not have been their choice at all, if the option of keeping the child had been available to them. These dynamics are evident in the story of Mary, 34, and similar issues were present in many others. Mary, as most birth mothers, had other children cared for by her aunt in the rural areas where it was cheaper to live. Mary was in the city trying desperately to find employment. She was currently the sole provider for the unemployed aunt and her other children, even though she only had some temporary piece jobs. She had placed her infant for adoption a month previously. Mary explained her hardships with these words. Her responsibility for her extended family's well-being was huge.

[Life] was difficult for me now, because I've got other children. [...] But now that I saw them life is difficult. [...] I took children to [the rural area], so I just stay here. So that's why I gave the baby for adoption. [...] Because for now I'm homeless, I'm not working. [...] My other children at home don't even have shoes to go to school. [...] Look at the children. I don't have enough things to give them, the right thing that they want, so you see. That is the other child's. When I'm starting to sit down, to feed the baby until two years, two, three years, so what's going on? What would have happened to us? And she was not working, my aunt. They [are] all looking for me. 
There was consequently a discernible narrative of blocked decision-making, exemplified as, "I chose adoption because I had no choice," and in comments such as: "I love this baby, but I don't have choice in the situation,"(Hope, 20, child adopted a week earlier) and "I have no choice." (Petunia, 24, had signed consent form) As is evident from these and other birth mother narratives, it was not just a question of not having enough money, it was also about not being able to secure the necessities of life. Lily's (37) story was perhaps the most heart-breaking. She had recently given birth and was still staying in the maternity home, while her baby was in a separate place of safety. Lily explicitly stated that she did not want her baby to be adopted. She wanted to have help so she could raise her child. As she remarked, such assistance was not available. Lily's account makes visible the disempowerment and feelings of entrapment of those who do not have access to even the basic means of survival. Lily was in a tunnel that could only lead to one outcome, the loss of her child. She knew that once she had been to court and it was established that she had no means to care for her baby, it would be placed for adoption. As she explained:

You see, I'm very worried. Every day I'm worried and they are coming to see me every day, if they are ready to take the baby. [...] Because it is not easy. (Cries) It is not easy. [...] I want to take baby but I can’t. Because I have got nothing. I have got nothing. I'm afraid to tell the court because I have got nothing. [...] If I'm going to sign, I will never find the baby, 
because if you want the baby back, it's just two months. But now I have got nothing. And can't find job.

Many other birth mothers explicitly stated that they would have preferred temporary care for their child so that they would not have lost all contact and rights over their child. The mothers hoped that they could get their child back after a while, when they would be in a better material situation. No such temporary care options were available, however. As one of the mothers, Simphiwe, 29, explained, she was constantly haunted by her increasing suspicion that maybe she could have managed to raise her child. She had placed her child for adoption two years earlier, and was currently working as a cleaner at an optometrist's. She lived with her six-year-old child and her own mother. She was HIV-positive but was currently in a very good physical condition and with the increased availability of antiretroviral drugs her future did not look bad. As she pointed out, she lacked any other options at the time of adoption. Simphiwe's account also makes visible the birth mother's sorrow and longing for her child. Other studies show that birth mothers do not move on and forget; instead they report feelings of sadness and grief, and the child remains "in their heart" (Fravel et al. 2000; Henney et al. 2007; Modell 1994, 61-90).

I just asked, I found out, I was sick and I thought, I wanted to do, what do they call it, not adoption but I wanted them to take the baby for a while and then, yes, foster care. So they told me it's not possible. [...] Because 
they said I can work, I'm not that much sick and my CD4-count is still good and I'm still working so there is a big ground that I can keep the baby, so. That's why they said it's not possible. And adoption is possible. It was so sad. I'm still missing her.

The adoption system looks different if the perspective is widened from the isolated child to include the mother of the child and the broader context of how this child was made available for adoption. This change of perspective makes it obvious that practices of the unequal world system and the unfair adoption system lead to the abandonment of the mothers by not offering them any assistance in keeping their children. In contexts of vital inequality (Therborn 2013) to do with lacking the basic means of survival, the birth mothers cannot afford to raise their children, which is then often the only reason for adoption. Despite the narrative of choice that is prevalent in the adoption system, birth mothers I interviewed pointed out their total lack of alternatives.

Inequality and lack of concrete measures to assist impoverished birth parents also lead to the undermining of the subsidiarity principle. According to the subsidiarity principle, it is the primary obligation of states to enable the child to remain in his or her family of origin. Only if this is not possible, and if a suitable permanent family cannot be found in the country of origin, should intercountry adoption be considered (HCCH 1993). Violations of the subsidiarity principle are thus a wider problem of the whole adoption system. Individual social workers I interviewed lacked resources and could not assist 
the mothers, even though they wanted to. Many of them criticised the practices, but removing the child from circumstances of severe malnutrition was often their only option.

\section{Removing the mothers from the picture}

As the dictionary meanings show, abandonment carries with it strong connotations of desertion and of the break being permanent and complete in the sense that the person who abandons is considered to have no further interest in the one they abandon. The international adoption system sees abandonment in these terms, indicating that such a child is deserted, unwanted and permanently left (see also Panter-Brick 2000, 21-22). As many researchers point out, at the back of this tendency to interpret all physical separations between parent(s) and children as abandonment is the image of the Global North type of financially stable and exclusive family with one set of parents and their children living together in the family home (King 2008/2009, 444-450; Yngvesson 2010). In this light, all other, different family structures appear dysfunctional.

The adoption system works with the Global North family model. It is stated in the Hague Convention (HCCH 1993) that "intercountry adoption may offer the advantage of a permanent family to a child for whom a suitable family cannot be found in his or her State of origin". In Finnish adoption law the "suitable" family is equated with an adoptive family: international adoption comes into question for a child "who needs 
adoptive parents and for whom suitable adoptive parents cannot be found in the country of origin" (Finlex 2012, 33§). A "proper" family is, in other words, understood to be permanent and to involve intensive parenting practices in a materially successful exclusive domestic setting. When such family notions are applied in the different contexts of the Global South, many children appear to lack family care. The different family structures in the South may involve extended rather than nuclear family forms as well as temporary separations between mothers and their children, during which the children are taken care of by grandparents or other kin (see Högbacka 2016). Temporary foster care or care by kin, which could lead to the reunification of the child with the family of origin at a later stage, is left out of the Global North type of family ideal and permanent separation in the form of adoption is applied (see King 2008/2009, 444-450; Yngvesson 2010). Adoption is even depicted as "saving" these abandoned children, who are seen as languishing in institutions (Varnis 2001). In reality, children's homes may be used by birth mothers as temporary safe places for children while the mothers try to find jobs or otherwise seek to improve their material situations (Högbacka 2016). In addition, the removal of any 'extra' parents, such as birth mothers, from the constellation of the exclusive adoptive family is seen as necessary for the well-being of the child (and the adopters). This tendency is evident in major international treaties governing intercountry adoption, such as the Hague Convention (HCCH 1993), and national legislations. Birth parents are only mentioned in passing in the context of their 
consent being needed in order to legitimise adoptions. After adoption, the child's ties with birth parents and kin are severed. Birth mothers are instructed to stop thinking about their children and to move on. Birth mothers are told that after the adoption it is "like the child is dead to her" (Yngvesson 2003, 20). Fonseca (2011) and Yngvesson (2002; 2004, 212-216) criticise such exclusivity, pointing out the impossibility of completely severing past ties, and the adverse effects on birth parents and adoptees. In South Africa and many other countries, the child is considered abandoned if there has been no contact between the child and the parents for three months (South African Children's Act 38 of 2005, Section 1b). From the point of view of birth mothers, in contrast, leaving the child in a place of safety or with other carers is an act of caring for the child in difficult material situations. As indicated in my birth mother interviews, three months can also be a short time if the mother is trying to sort things out in straitened circumstances, and intends to return.

The South African adoption social workers embodied and implemented the values and norms of the wider adoption system. They viewed traditional child care practices within the extended family, in which the mother might live elsewhere, as detrimental and harmful. They considered such childcare arrangements to lead to street children and delinquency. In their view only permanent exclusive families could guarantee proper care. As is illustrated in the following social worker's account, even care within the child's extended family is viewed negatively and care with total strangers is held to be 
better. This leads to domestic solutions, like foster care or care within the extended family, to be seen as inadequate and inferior to Global North adopters. The children are in fact seen to have a right to be adopted by Global North parents. In reality adoption is not well understood among black South Africans, because it is alien to the traditional kin care model. Extended family members are also disinclined to consider adopting the child because they would then lose the foster care grant, which for many is paramount to survival. This is not considered by social workers:

We really want to move away from the traditional view, welfare view of childcare and look at permanency planning for children. Foster care and the children's home placement for us would be a very last resort. [...] Because we do believe that stability in terms of a family is the right of every child. And foster care is not a stable situation. It should be just a temporary solution. So if we are looking at foster care generally we're looking at foster care for extended family members and the majority of our foster-care placements are with extended families to keep the child within the family, but also as a means of the biological parents retaining a right over that child. It's a formalising of what once was an informal situation. It's really not the premise we will bolt on, we believe very strongly in permanency planning. (Adoption social worker, interview No. 9) 
Social workers understood all separations as permanent. There was a subsequent interpretation that children left in children's homes by the mother were abandoned, i.e. deserted, and that the mothers were not going to return and that the children should be adopted as quickly as possible. There were comments such as: "I think we have children that are abandoned and that end up in foster care, which is not permanent. And that we should change. We have children that are abandoned in children's homes. I know that for a fact. They have no contact whatsoever and those children are not available for adoption system and they should [be]." (adoption social worker, interview No. 5) Social workers were very concerned about birth parents not wanting to sign away all rights to the child. This is also evident in another researcher's descriptions of South African adoption social workers: "Of greatest concern to the social workers, are the children who are left in institutions or in the foster care system by parents who are known, but who are unwilling to take care of them. These parents are not prepared to relinquish their rights to their child.” (Blackie 2014, 56) Social workers also complained about birth mothers who came back after one or two years wanting to take back their child. Social workers thus still stuck to the idea of abandonment, even in the face of it being obvious that the mother had not intended for the separation to be permanent. As a social worker explained:

We've had birth mothers abandoning children in hospital and going away that we haven't been able to counsel that might come back two years later 
and said 'I just wanted somebody to keep the child for a while, but I want my child back'. And then it's very difficult to work with them. But 'no, we've placed this baby for adoption. You can't have the child'. (Adoption social worker, interview No. 5)

Social workers also feared multiple parenthood, stating that after adoption all contact between the birth mother and the child and the adoptive family should gradually be abolished. According to the two-year-rule they applied, contact in the form of news about the child sent by adopters to the adoption organisation was beneficial for the mothers in the beginning years but after that it should end. Social workers considered this to be best for the mother, who needed to "move on" (interview No. 6), for the adopters (interview No. 4) and for the child, who "needed to belong" and "not be confronted with both heritages" (interview No. 5). Adoption social work was designed to gradually distance the birth mother from the adoptive family and the child, in the end removing her completely by ceasing all contact.

The differences of these family notions result in differences in how adoption is understood in the adopting countries (and by the adoption system) and by birth parents. Esther Goody (1982) shows how such cultural notions were behind the misunderstanding in cases in which West African immigrants in England considered the fosterage of their children in English families to provide the children with superior educational opportunities, and expected them to return. The English families thought 
that the arrangement would lead to adoption of these "unwanted" children (Goody 1982, 217-233). As she says: "We [Westerners] see nurturance and socialization as necessary elements of 'true parenthood' and thus [...] parents who do not fill these rearing roles 'cannot really deserve their children' - for us they cease to be parents.” (Goody 1982, 279) The Global North's association between non-residential parenting and abandonment is clear.

South African birth mothers' own descriptions made it clear that some mothers had left their children to be cared for in children's homes or other places of safety and were planning to return when their material situations had improved. As I showed, many would have preferred temporary solutions, in which the child could have been looked after for some time while the mother tried to find a job. The birth mothers furthermore made it clear that they were not abandoning the children, they instead wanted to remain in contact and to know what happened in the child's life. They did not lose interest. Thus the notion of the abandoned child as unwanted and the birth mother as losing interest in what happens to the child are unfounded. Birth mothers emphasised that they wanted to look after the child and wanted to know where the child went and how it fared post-adoption. As is evident in the following comments by three birth mothers, receiving information was crucial to the well-being of the mother. Cathy, 30, who had placed her child for adoption seven years earlier, explained to me that she "didn't wanna like get rid of it [the child]", but "just wanted someone like take care of it". Natie, 27, 
had relinquished her child a year previously. She wanted to know "what's happening in this child's life". Mary, 34, emphasised that she "did not want to throw away of my child altogether", referring to her wish to receive information about it post-adoption. Mary's child had been placed with adopters a month earlier.

In contrast to the linear conception of adoption as a permanent removal of the child from the birth family to the adoptive family with no messy ties, birth mothers adhered to the idea of circular movement. One of the most striking themes in the interviews was the widespread expectation of the return of the child when of age (see also Roby and Matsumura 2002, 24). These first mothers still considered the children they had placed for adoption, who were now living in another country, part of their original families, and were certain that they would want to know them. There was a very strong wish and a belief that one day they would meet their child again, that the child would return when of age. The future return of the child was mentioned by many of the first mothers who received letters and/or photographs through social workers, and by many of those who were still pregnant and had made adoption plans (see Högbacka 2016). The mothers made comments such as the following, which highlighted the continuing tie between the child and the original kin.

I love the child, I want, when he was eighteen, God knows, maybe I will be alive. So when he meet me. (Mary, 34, child adopted a month earlier) 
'Cause that baby, she will come maybe after eighteen years. She want to see me. So I think I must tell them that there's another baby. (Hope, 20, child adopted a week earlier)

I'm hoping that some time before I don't know when but that the child will come round and look for us. 'Cause I think that will happen. (Lucille, 38 , child adopted 12 years earlier)

When he has his own rights, he will come and look for us. (Meg, 22, child adopted three years earlier)

Some mothers commented without being prompted that the adopted child was still part of the family. Gugu said that she wanted to maintain connections because the child was still hers on some level. Instead of cutting all ties and forgetting, she wanted to be there for the child later. These comments show that the physical location of the child is not the decisive factor. Not living with the child does not cancel out motherhood. Even though adoption social workers explained the nature of adoption, the clean break that is typical of Western adoption did not happen in the minds of these birth mothers. Their views were clearly influenced by the more familiar practice of informal kinship care. Adoption is thus not viewed as losing the child forever. Birth mothers, however, are dependent on the adopters. If the adoptive families do not want to send any news or maintain contact with the birth mother, there is very little the birth mothers can do. 
At the end of the day, it's my child. And maybe ten, ten years, fifteen years down the life the child will want to come to South Africa, so it's going to be difficult to interact with the child if you just close everything. [...] I know there will be time that child would like to see his mother and then I will be available, and I will be ready that time. (Gugu, 34, child adopted 1.5 years earlier)

The three meanings of abandonment that I have identified, namely abandonment as leaving someone without help, as a permanent break and as indication of being unwanted, take on different meanings when looked at from the point of view of the birth mothers. It seems that it is the mothers who are abandoned and unwanted. The practices of intercountry adoption tend to leave birth mothers to their own devices without offering them assistance to keep their children. In addition, the exclusionary principles of clean-break family formation cut birth mothers out of the newly formed adoptive family. Instead, birth mothers themselves overwhelmingly emphasised their need to receive news about the child after adoption. The children were thus not unwanted: destitute birth mothers had to use adoption as the only way of caring for their children.

\section{The social production of abandonment}

Although intercountry adoption can and does provide homes for children who otherwise would not have families, the issue is more complicated. The adoption system is based 
on a world system which impoverishes the majorities in the Global South and creates affluent families in the North. Because of its embeddedness in the global structures of inequality, intercountry adoption also participates in the production of abandonment, which is then used as a reason and justification for adoptions. Current adoption practices further perpetuate a highly unjust system in which the children of impoverished and distressed birth mothers are removed for adoption instead of first offering the mothers other alternatives. The mothers themselves would have preferred temporary solutions and assistance in the form of child care, job opportunities and housing. By not enabling other care options that would not result in permanent breaks between mothers and their children, the adoption system produces such breaks, which are then interpreted as abandonment. Individual social workers can do very little within such circumstances. It is the mothers themselves who are abandoned first: although in need of assistance they are offered none.

The Global North-South divide at the heart of intercountry adoption also produces ethnocentric understandings, values and norms, which work to the advantage of the more powerful Global North adopting nations. The family and parenting notions prevalent in the adoption system prioritise the exclusive nuclear family models of the Global North, which are then imposed on the different family structures of the Global South. Children who are not embedded in nuclear parenting families but who nevertheless are cared for within kin networks are seen as abandoned by the adoption 
system, which then proceeds to place these children in Global North adoptive families. Due to these same exclusive family notions, birth mothers are interpreted as a disturbance and a threat to the belonging of adoptive families. Birth mothers do not fit within the boundaries of proper families with one set of parents. Birth mothers are easily cut out of the picture and are rendered invisible and non-existent under the pretext of such ties not being in the best interests of the child. The adoption system itself thus creates permanent breaks between mothers and children.

The child-centred focus of adoption practices and social work and the tendency to view the child in opposition to and separately from the birth mother is problematic. Rather, the rights and well-being of the children cannot be completely separated from their birth mothers. As others have argued, the child is, initially, a member of the family of origin. Hence, harming the birth parents also harms their child (Smolin 2007b). Another study with Brazilian adoptees suggests that the way the birth parents had been treated by the adoptive parents (and the adoption system) had a great influence on adoptees' wellbeing and on their relations with their adoptive parents (Fonseca 2011, 331-332).

It is clear from these remarks that the international adoption system needs serious revision. Focus should be shifted from Global North adopters to Global South birth families. Instead of looking at the children through the norms of the Global North, they should be placed within the context of pre-existing kin structures. Before proceeding with adoption, birth mothers should be listened to more carefully. Their struggles to 
keep their children should be honoured and aided by concrete assistance. Where possible, ties between birth family members and children should be maintained after adoption. It is only through such measures that intercountry adoption can shake its Global North bias and become a potential destabiliser of global power structures by making interventions to aid those whom the system oppresses.

\section{Funding acknowledgements}

At the various stages of my larger study, of which this article is a part, I have received funding from the Kone Foundation, the Academy of Finland, the Jenny and Antti Wihuri Foundation, the Finnish Cultural Foundation and the Emil Aaltonen Foundation.

\section{References}

Bhambra, G. K. (2014). Connected sociologies. London/New Delhi/New York/Sydney: Bloomsbury.

Blackie, D. (2014). Sad, mad and bad: Exploring child abandonment in South Africa. Master's Thesis, Department of Anthropology, University of Witwaterstrand, March 2014. Available at: http://www.adoptioncoalitionsa.org/dbthesis/. (Accessed 12 Oct 2016.) 
Bos, P. (2007). Once a mother. Relinquishment and adoption from the perspective of unmarried mothers in South India. PhD Dissertation, Radboud University Nijmegen, The Netherlands.

Cambridge dictionary. Available at:

http://dictionary.cambridge.org/dictionary/english/abandon. (Accessed 20 Nov 2016.)

Cantwell, N. (2014). The best interests of the child in intercountry adoption. Florence: Innocenti Insight and UNICEF Office of Research. Available at:

https://www.unicef-irc.org/publications/712/. (Accessed 12 Oct 2016.)

Castles, S. (2003). Towards a sociology of forced migration and social transformation. Sociology, 37(1): 13-34.

Finlex. (2012). Adoptiolaki 22/2012 (Finnish adoption law). Available at:

http://www.finlex.fi/fi/laki/alkup/2012/20120022?search\%5Btype\%5D=pika\&search\% 5Bpika\%5D=adoption. (Accessed 12 Oct 2016.)

Fonseca, C. (2011). The de-kinning of birthmothers - Reflections on maternity and being human. Vibrant, 8(2): 307-339.

Fravel, D. L., McRoy, R. G., \& Grotevant, H. D. (2000). Birthmother perceptions of the psychologically present adopted child: Adoption openness and boundary ambiguity. Family Relations, 49(4), 425-433.

Giberti, E. (2000). Excluded mothers. Birth mothers relinquishing their children. In P. Selman (Ed.), Intercountry adoption. Developments, trends and perspectives. London: British Agencies for Adoption and Fostering, pp. 458-466.

Goody, E. (1982). Parenthood and social reproduction. Cambridge: Cambridge University Press.

Hall, K., Meintjes, H., \& Sambu, W. (2014). Demography of South Africa's children. In S. Mathews, L. Jamieson, L. Lake, \& C. Smith (Eds.), South African Child Gauge 2014. Cape Town: Children's Institute, University of Cape Town. 
http://www.ci.org.za/index.php?option=com_content\&view=ar

ticle\&id=1122\&Itemid=697. Accessed 12 Oct 2016.

HCCH. (1993). Hague convention on protection of children and co-operation in respect of intercountry adoption. Available at:

https://assets.hcch.net/docs/77e12f23-d3dc-4851-8f0b-050f71a16947.pdf. (Accessed 12 Oct 2016.)

Henney, S. M., Ayers-Lopez, S., McRoy, R., \& Grotevant, H. D. (2007). Evolution and resolution: Birthmothers' experience of grief and loss at different levels of adoption openness. Journal of Social and Personal Relationships, 24(6), 875-889.

Högbacka, R. (2016). Global families, inequality and transnational adoption. The dekinning of first mothers. London: Palgrave Macmillan.

King, S. (2008/2009). Challenging monohumanism: An argument for changing the way we think about intercountry adoption. Michigan Journal of International Law, 30 (Winter), 413-470.

Merriam-Webster. Available at. http://www.merriam-webster.com/dictionary/abandon. (Accessed 20 Nov 2016.)

Modell, J. (1994). Kinship with Strangers. Berkeley, Los Angeles and London: University of California Press..

Nieuwenhuys, O. (2013). Theorizing childhood(s): Why we need postcolonial perspectives. Childhood, 20(1): 3-8.

Oxford living dictionaries. Available at:

https://en.oxforddictionaries.com/definition/abandon. (Accessed 20 Nov 2016.)

Panter-Brick, C. (2000). Nobody's children? A reconsideration of child abandonment. In C. Panter-Brick \& M. T. Smith (Eds.), Abandoned children. Cambridge: Cambridge University Press, pp. 1-26.

Penn, H. (1999). How should we care for babies and toddlers? An analysis of practice in out-of-home care for children under three. Childcare Resource and Research Unit, 
Centre for Urban and Community Studies, Occasional Paper 10. Available at: http://www.childcarecanada.org/sites/default/files/op10.pdf. (Accessed 12 Oct 2016.)

Penn, H. (2009). The parenting and substitute parenting of young children. In G. Bentley \& R. Mace (Eds.), Substitute parents. New York/Oxford: Berghahn Books, pp. 179-193.

Perry, T. L. (1998). Transracial and international adoption: Mothers, hierarchy, race, and feminist legal theory. Yale Journal of Law and Feminism, 10, 101-164.

Pratt, M. L. (2002). Modernity and periphery: Toward a global and relational analysis. In E. Mudimbe-Boyi (Ed.), Beyond dichotomies: Histories, identities, cultures, and the challenge of globalization. Albany: State University of New York Press, pp. 21-47.

Roby, J., \& Matsumura, S. (2002). If I give you my child, aren't we family? A study of birthmothers participating in Marshall Islands - U.S. adoptions. Adoption Quarterly, 5(4): 7-31.

Smolin, D. (2007a). Intercountry adoption and poverty: A human rights analysis. Capital Law Review, 36(2): 413-453.

Smolin, D. (2007b) Child laundering as exploitation: applying anti-trafficking norms to intercountry adoption under the coming Hague regime. Vermont Law Review Vol. 32: $1-55$.

South African Children's Act 38 of 2005. Available online at: http://www.justice.gov.za/legislation/acts/2005-38\%20childrensact.pdf. (Accessed 12 Oct 2016.)

South African Children's Act 38 of 2005. Available online at: http://www.justice.gov.za/legislation/acts/2005-038\%20childrensact.pdf (accessed 4 August 2017).

South African Government Info. (2014).

http://www.gov.za/services/servicesresidents/social-benefits. Accessed 12 Oct 2016. 
South African Government Info. (2014) Available online at:

http://www.gov.za/services/services-residents/social-benefits (accessed 4 August 2017).

Therborn, G. (2013). The killing fields of inequality. Cambridge: Polity Press.

United Nations General Assembly. (2010). Guidelines for the alternative care of children. A/ Res/64/142. New York: United Nations Human Rights Council, http://www.unicef.org/protection/alternative_care_Guidelines-English.pdf, accessed 9 Oct 2016.

Varnis, S. L. (2001). Regulating the global adoption of children. Society, 38(2): 39-46.

West, R. (2014). From choice to reproductive justice: De-constitutionalizing abortion rights. In R. West, J. Murray, \& M. Esser (Eds.), Gender in law, culture, and society: In search of common ground on abortion: From culture war to reproductive justice.

Burlington: Ashgate, pp. 19-51.

Yngvesson, B. (2002). Placing the "Gift Child" in transnational adoption. Law and Society Review, 36(2): 227-255.

Yngvesson, B. (2003). Going "Home". Adoption, loss of bearings, and the mythology of roots. Social Text, 74, 21(1): 7-27.

Yngvesson, B. (2004). National bodies and the body of the child. 'Completing' families through international adoption. In F. Bowie (Ed.), Cross-cultural approaches to adoption. London/New York: Routledge, pp. 211-226.

Yngvesson, B. (2010). Belonging in an adopted world. Race, identity, and transnational adoption. Chicago: The University of Chicago Press. 